УДК 336.714

\title{
ОЦЕНКА И ПЕРСПЕКТИВЫ РАЗВИТИЯ ПРЯМЫХ ИНВЕСТИЦИЙ В РОССИЮ (НА ПРИМЕРЕ ИСПАНИИ)
}

Неуступова А.С.

к.э.н., доцент

Санкт-Петербургский государственный морской технический университет

Аннотация: В статье рассматривается вопросы прямых инвестиций и их эффективность в экономике России в настоящее время в условиях санкций и последствий пандемии на примере испанских энергетических компаний. Делается вывод, что прямые зарубежные инвестиции представляют собой также способ повышения производительности и технического уровня российских предприятий. Иностранная компания приносит с собой новые технологии, новые способы организации производства и прямой выход на мировой рынок.

Ключевые слова: прямые инвестиции, особенности прямых иностранных инвестиций, иностранные технологии, новые технологии.

\section{ASSESSMENT AND PROSPECTS FOR THE DEVELOPMENT OF DIRECT INVESTMENT IN RUSSIA (ON THE EXAMPLE OF SPAIN)}

\section{Neustupova Alina Serafimovna}

\begin{abstract}
The article examines the issues of direct investment and its effectiveness in the Russian economy at the present time in the context of sanctions and the consequences of the pandemic on the example of Spanish energy companies. It is concluded that foreign direct investment is also a way to increase the productivity and technical level of Russian enterprises. A foreign company brings with it new technologies, new ways of organizing production and direct access to the world market.

Key words: direct investment, features of foreign direct investment, foreign technologies, new technologies.
\end{abstract}


Инвестиции играют большую роль в поддержании и увеличении экономического потенциала страны. Это, в свою очередь, ведет к увеличению валового национального продукта, повышает активность страны на внешнем рынке. Именно поэтому инвестиционная деятельность становится важным объектом внимания в процессе проведения крупных политических, экономических и социальных преобразований.

Проблема инвестиций особенно актуальна в нашей стране. Дефицит бюджета, который наблюдается в современной кризисной ситуации, не позволяет государству своими силами улучшить положение в стране. Помочь правительству в преодолении кризиса могут инвестиции. Российский рынок один из самых привлекательных для иностранных инвесторов, но в то же время он также считается один из самых непредсказуемых. Так, иностранные инвесторы находятся в неопределенном положении, пытаясь, с одной стороны, не упустить свою выгоду и, одновременно, не потерять свои деньги.

Ежегодно в РФ приходит капитал из более чем 100 стран мира. Среди основных партнеров России выделяются Кипр, Великобритания, США, Франция, Япония, Нидерланды, Люксембург, Китай, Швейцария, Ирландия.

Очевидно, что Испания не самый крупный инвестор России, но последние время наблюдался рост интенсивности российско-испанских межрегиональных отношений. Для успешного сотрудничества и у Испании и у России есть хорошие перспективы, необходимо правильно их развивать.

В Федеральном законе «Об инвестиционной деятельности в Российской Федерации, осуществляемой в форме капитальных вложений» дается следующее определение термину «инвестиции». «Инвестиции - денежные средства, ценные бумаги, иное имущество, в том числе имущественные права, иные права, имеющие денежную оценку, вкладываемые в объекты предпринимательской и (или) иной деятельности в целях получения прибыли и (или) достижения иного полезного эффекта»[1].

Прямые иностранные инвестиции - иностранные инвестиции, достаточно крупные для того, чтобы позволить инвестору установить эффективный контроль за управлением предприятием и создать у него долговременную заинтересованность в успешном функционировании и развитии этого предприятия. По методике МВФ - иностранные инвестиции, распространяющиеся на 10 и более процентов голосующих акций.

В соответствии с законом РФ «Об иностранных инвестициях» иностранные инвесторы могут осуществлять инвестирование на территории страны путем: 
1. долевого участия в предприятиях, создаваемых совместно с российскими юридическими лицами и гражданами (совместные предприятия);

2. создания предприятий, полностью принадлежащих иностранным инвесторам, а также филиалов иностранных юридических лиц.

Государство гарантирует, что иностранным инвестициям будет предоставлена полная правовая защита, а также гарантии от национализации и других мер, от незаконных действий государственных органов и их должностных лиц, а также ряд льгот в зависимости от целей инвестирования.

Таким образом, Россия как страна, заинтересованная в привлечении иностранных инвестиций, принимает участие в двусторонних и многосторонних соглашениях, которые обычно включают в себя следующие основные обязательства:

1. создавать благоприятный режим для капиталовложений инвесторов и связанной с ними деятельности;

2. обеспечить надлежащую защиту иностранной собственности;

3. предоставить инвесторам возможность беспрепятственного перевода доходов, полученных от инвестиционной деятельности;

4. гарантировать рассмотрение споров в международном арбитраже.

Необходимо отметить, что иностранные инвесторы также получают конкурентное преимущество перед российскими компаниями за счет использования инструментов международного налогового планирования, то есть за счет более низкого размера налогового бремени. Кроме того правовой режим деятельности иностранных инвесторов и использования полученной от инвестиций прибыли не может быть менее благоприятным, чем у российских инвесторов, за исключением случаев, устанавливаемых федеральными закона [2].

Развитие российско-испанских внешнеторговых отношений Правительство Испании считает перспективным. По оценкам специалистов, что испанская сторона нуждается в импорте энергоресурсов, а потому заинтересована в расширении своего присутствия на российском потребительском рынке, в привлечении испанских компаний к реализации российских инфраструктурных проектов. [3] В свою очередь России полезны испанские технологии и промышленное оборудование, инвестиции в инфраструктурные и промышленные объекты. История развития российскоиспанских отношений является хорошей основой для дальнейшего сотрудничества. Еще 2010-2013 гг. были подписаны контракты по сотрудничеству в энергетической отрасли, автомобилестроении, 
существенные инвестиции были также осуществлены и в химической промышленности. В 2013 г., до введения экономических санкций, Россия входила в десятку крупнейших торговых партнеров Испании. 2014-2015 гг. в связи с участием Испании в торгово-экономических санкциях ЕС в испанороссийских отношениях возникли существенные сложности: снизились объемы поставок, уменьшилось количество испанских предприятий на российском рынке. Так к примеру, с 2008 по 2010 года испанские инвестиции в Россию составляли 528,4 млн евро, а в течение следующих 10 лет они уменьшились до 218,2 млн евро.

Один из наиболее важных секторов, где инвесторы Испании способны внести значительный вклад в модернизацию России - энергетический сектор. Отметим следующие две крупные компании, которые присутствуют на российском рынке, это Iberdrola и Repsol.

Iberdrola - производитель и поставщик электроэнергии, также является одним из крупнейших в мире операторов возобновляемых источников энергии [3]. Стоит отметить, что данная энергетическая компания приступает реализации проекта на Урале. В Пермском крае на реке Кама испанская компания построит распределительный узел-подстанцию на 500 киловольт. Эта установка войдет в каскад сооружений Воткинской гидроэлектростанции, производящей 1,2 мегаватт электроэнергии. Iberdrola выиграла конкурс на это строительство, благодаря своим работам на Среднеуральской ГРЭС (Свердловская область), где сдала под ключ аналогичную подстанцию, работы над данным объектом привели к внедрению новых технологий пригодных для использования в неблагоприятных погодных условиях.

Repsol - крупнейшая нефтегазовая компания в Испании и Латинской Америке. Repsol пришла в Россию в 2006 году, приобретя часть акций компании (10\%) West Siberian Resources. Компания проявляет интерес к эксплуатации газового месторождения на Ямале в сотрудничестве с Газпром, а также к участию в проектах, связанных с сжиженным природным газом. Repsol еще в 2015 году объявила о намерении построить завод на Ямале стоимостью 6 млрд. долларов [4].Однако необходимо отметить, что принятые санкции привели к замораживанию некоторых двухсторонних проектов, связанных с данными компаниями.

Расширение российско-испанского сотрудничества в современных условиях является непростым вопросом, однако прямые зарубежные инвестиции - это нечто большее, чем простое финансирование капиталовложений в экономику, хотя само по себе это крайне необходимо 
Российской Федерации. Прямые зарубежные инвестиции представляют собой также способ повышения производительности и технического уровня российских предприятий. Размещая свой капитал в Российской Федерации, иностранная компания приносит с собой новые технологии, новые способы организации производства и прямой выход на мировой рынок.

\section{Список литературы}

1. Федеральный закон от 25.02.1999 N 39-ФЗ (ред. от 08.12.2020) "Об инвестиционной деятельности в Российской Федерации, осуществляемой в форме капитальных вложений" htp://www.consultant.ru/document/cons_doc_ LAW_22142/bb9e97fad9d14ac66df4b6e67c453d1be3b77b4c/

2. Федеральный закон "Об иностранных инвестициях в Российской Федерации" от 09.07.1999 N 160-Ф3 http://www.consultant.ru/document/ cons_doc_LAW_16283/

3. https://ru.wikipedia.org/wiki/Iberdrola

4. https://ru.wikipedia.org/wiki/Repsol 